\title{
Statistical Optimization, Partial Purification, and Characterization of Phytase Produced from Talaromyces purpureogenus NSA20 Using Potato Peel Waste and its Application in Dyes De-colorization
}

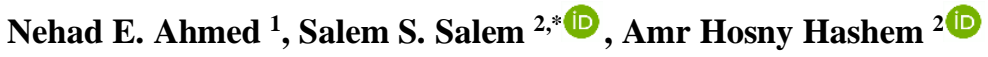 \\ 1 Chemistry of Natural and Microbial Products Department, Pharmaceutical Industries Research Division, National \\ Research Centre, Dokki, Giza 12622, Egypt \\ 2 Botany and Microbiology Department, Faculty of Science, AL-Azhar University, Nasr City, Cairo-11884, Egypt \\ * Correspondence: salemsalahsalem@azhar.edu.eg;
}

Scopus Author ID 57202162965

Received: 5.04.2021; Revised: 5.06.2021; Accepted: 10.06.2021; Published: 15.08.2021

\begin{abstract}
In this study, Talaromyces purpureogenus NSA20 as phytase-producing marine fungus was isolated and identified morphologically and genetically and deposited in Gene Bank with accession number MW031769.1. One factor at a time (OFAT) optimization was performed, where the result revealed that potato peel waste $(1.5 \%)$ as a substrate was the highest for phytase production at 6 days, where the maximum activity of phytase was $138.4 \mathrm{U} / \mathrm{ml}$. Moreover, Box-Behnken design as response surface methodology was carried out for statistical optimization of phytase production by $T$. purpureogenus NSA20. Statistical optimization illustrated that the optimized medium for phytase production increased 1.57 fold compared to the OFAT optimized medium. Partial purification of phytase was carried out, where the enzyme after precipitation with ammonium sulfate (80\%) was 2.6fold purified phytase, and the yield was $39.8 \%$., the specific activity was $31.19 \mathrm{U} / \mathrm{mg}$ proteins. Additionally, partially purified phytase was characterized; the maximum activity of phytase at $\mathrm{Fe}++$ $0.1 \%$ and $\mathrm{pH} 5.5$ at $37 \mathrm{oC}$ was $350 \mathrm{U} / \mathrm{ml}$. Eventually, phytase was applied for crystal violet and methyl red decolorization, where decolorization percentages of crystal violet and methyl red were $85.5 \%$ and $75 \%$ at $120 \mathrm{~min}$, respectively.
\end{abstract}

Keywords: Talaromyces purpureogenus; phytase; statistical optimization; Box-Behnken design; dye decolorization.

(C) 2021 by the authors. This article is an open-access article distributed under the terms and conditions of the Creative Commons Attribution (CC BY) license (https://creativecommons.org/licenses/by/4.0/).

\section{Introduction}

Phytic acid [myo-inositol hexakisphosphate (IP6)], known as phytate, organic phosphorous storage, is in the form of phytic acid in most plant tissues [1]. Many crops are useful sources of essential nutrients; however, they contain high phytic-acid values, which may be considered an anti-nutritional factor [2,3]. Phytic acid is an indigestible constituent for humans and animals; phytic acid has a strong binding affinity to cations such as iron, magnesium, calcium, and zinc, forming complexes insoluble in the intestinal, which leads to inhibition for the absorption of minerals $[4,5]$. Moreover, phytic-acid complexes form with protein molecules, causing lower digestibility and solubility, reducing their nutritive value [6, 7]. Besides, phytic-acid chelates vitamin (B3), causing Pellagra, a vitamin- deficiency disease. Phytases (myo-inositol hexakis-phosphate 3-phosphorylase, EC 3.1.3.8 and myo-inositol 
hexakis-phosphate 6-phosphorylase, EC 3.1.3.26) are classified as the family of histidinic acid phosphatase which hydrolyzes of phytate to lower phosphorylated myo-inositol derivatives or in some cases to free myo-inositol and inorganic phosphate (Pi) [8]. Phytase is an enzyme that frees the in-organic phosphorous from the phytate complex. It addresses both the eutrophication problem and anti-nutritional; this results in increased availability of amino acids, minerals, trace elements, and phosphate [2]. Phytate degrading enzymes (phytases) have wide applications; it is an enzyme of economic importance due to its potential applications in the food and feed industries, in the formation of myo-inositol phosphate, in agriculture, and the pulp and paper industry [9-12]. But the commercial use is hindered by the high cost of production, which is attributed to the higher cost of the substrate and downstream methods [13, 14]. The high production cost can be overcome by the usage of cheap substrates like residues of agriculture [15]. Some agricultural waste such as wheat bran, citrus peels, wheat straw, rice bran, soybean meal, corn cobs, oil cakes, coconut oil cakes, and corn bran can be utilized as the best carbon source for phytase production. Phytases are widespread, and they are present in many plants, animal tissues, and microorganisms (bacteria, yeasts, and fungi) $[16,17]$. Fungi are known for their ability to produce extracellular-enzymes compared to intracellular-enzymes produced by bacteria and yeast cells, and this makes fungi cells attractive for large-scale production of enzymes [18]. Fungi and their metabolites are used in various applications and modern technologies [19-23]. Over 200 fungal cell isolates starting to the genera Penicillium, Mucor, Aspergillus, and Rhizopus have been identified as phytases active producers. Aspergillus species, namely Aspergillus ficcum, Aspergillus oryzae, Aspergillus niger, Aspergillus fumigatus, and Aspergillus carbonarius are considered as a good producers of phytase enzymes of industrial importance, and the most phytase source is A. niger [24]. Statistical experiment design provides an efficient optimization approach. Statistical experiment design is suitable for predicting the interactions between variables and identifying the most significant components in the medium [25]. A combination of factors starting a certain optimum factor response can be identified using factorial design and utilize of surface response methodology [25]. Increase the phytase production can become significant by employing statistical optimization techniques. This is because statistical optimization gives the optimum media with a minimum number of experiments in a short time while also considering the interaction between selected components [26]. This study aimed to isolate and identify a marine fungus that can produce phytase enzymes. Also, to optimize the production of phytase using response surface methodology to obtain the maximum production. Eventually, applying phytase in the dyes decolorization processes.

\section{Materials and Methods}

\subsection{Fungi isolation and culture conditions.}

Fungi were isolated from red seawater at Sharm El-Sheikh Governorate. Isolation of fungi was carried out by plating the inoculum on malt extract agar (MEA) (Oxoid) after serial dilutions of sample and incubated at $30{ }^{\circ} \mathrm{C}$ for 3-4 days. Contaminations of bacteria were inhibited by chloramphenicol $10 \mu \mathrm{g} \mathrm{mL}^{-1}$ after autoclaving. Colonies morphology were individually picked up and re-inoculated on (MEA) for purification, and the fungal cultures were maintained on (MEA), incubated at $30^{\circ} \mathrm{C}$ for 7 days, and stored at $4{ }^{\circ} \mathrm{C}$ [27]. 


\subsection{Morphological and molecular identification of the fungus.}

Fungal isolate NSA20 was selected for phytase production. Morphological identification of the fungus was carried out by observing the morphological characteristics (color, texture, and appearance) and microscopic characteristics using a light microscope $[28,29]$. Molecular identification was performed based on the $18 \mathrm{~S}$ rRNA gene. Genomic DNA was extracted utilizing the protocol of DNA purification. The regions were amplified in (PCR) utilizing the genomic DNA as template and primers NS1 5' (GTA GTC ATA TGC TTG TCT C) 3' and NS8 5' (TCC GCA GGT TCA CCT ACG GA) 3'. The 18S rRNA gene was compared against the Gen-Bank database utilizing the NCBI-BLAST program. Sequences were then compared with sequences in the Gen-Bank database utilizing BLASTN. Multiple sequence alignment was done, and a phylogenetic tree was constructed by software program.

\subsection{Production of phytase.}

T. purpureogenus NSA20 was inoculated in $250 \mathrm{ml}$ Erlenmeyer-flask containing $50 \mathrm{ml}$ of phytase screening medium containing $(\mathrm{g} / \mathrm{L})$ : Glucose 10.0; $(\mathrm{NH} 4)_{2} \mathrm{SO}_{4} 3.0 ; \mathrm{KCl} 0.5$; $\mathrm{MgSO}_{4} .7 \mathrm{H}_{2} \mathrm{O} 0.5 ; \mathrm{CaCl}_{2} 0.1$, Calcium phytate $\left.0.5 \%, \mathrm{pH} 5.5\right)$ and incubated at $30 \circ \mathrm{C}$ on a rotary shaker at $150 \mathrm{rpm}$, after 6 days fermentation, centrifuged at $4,000 \mathrm{rpm}$ for $15 \mathrm{~min}, 4^{\circ} \mathrm{C}$. the filtrate obtained was utilized in the phytase assay.

\subsection{Phytase and total protein assay.}

Phytase activity was evaluated by measuring the amount value of liberated inorganic phosphate as described by [30]. The reaction mixture consisted of $0.9 \mathrm{ml}$ of acetate buffer $(0.2$ $\mathrm{M}, \mathrm{pH} 5.5$ ) containing $1 \mathrm{mM}$ phytate and $0.1 \mathrm{ml}$ of enzyme solution. After incubation for 30 mins at $37{ }^{\circ} \mathrm{C}$, the reaction was ended by adding $1 \mathrm{ml}$ of $10 \%$ trichloroacetic acid. The liberated inorganic phosphate was measured according to [26]. One unit of phytase is defined as the amount value of enzyme releasing $1 \mu \mathrm{mol}$ of inorganic phosphorus per ml per minute under the assay conditions. The total protein content was carried out according to Bradford (1976) method.

\subsection{Optimization of culture conditions for the production of phytase.}

2.5.1. Effect of agricultural wastes on phytase production.

The different agricultural wastes as wheat bran, corn cobs, rice bran, rice straw, corn starch, soybean powder, orange peel, potato peel, and peanut peel were used as substrates for phytase production. All substrates were locally obtained, washed, dried at $70^{\circ} \mathrm{C}$, and milled utilizing a grinder before use. $0.5 \%$ of the different agricultural wastes were added as a carbon source in fermentation media inoculated with T. purpureogenus NSA20. Then, phytase activity was determined. One substrate was further selected to achieve the maximum phytase activity. The best waste concentration for maximum phytase activity was investigated using different concentrations ranging from 1 to $25 \mathrm{mg} / \mathrm{ml}$.

\subsubsection{Effect of incubation time on phytase production.}

To measure the optimum incubation time for T. purpureogenus NSA20 growth and phytase production, the fungal culture was cultivated in production medium and incubated for different incubation times $3,4,5,6$, and 7 at $30^{\circ} \mathrm{C}$ on an incubator shaker at $150 \mathrm{rpm}$. 


\subsubsection{Box-Behnken design.}

Based on the preliminary one factor-at-a-time experiments, factors that strongly affect phytase production were selected for Box-Behnken design; potato peel concentration, incubation time, and potassium di-hydrogen phosphate $\left(\mathrm{KH}_{2} \mathrm{PO}_{4}\right)$. Table 1 shows selected factors and their levels for Box-Behnken design, three levels for each factor were selected; where levels were $(1,1.5$ and $2.0 \%),(5,6$, and 7 days) and $(0,0.5$, and $1.0 \mathrm{~g} / \mathrm{l})$ for potato peel concentration, incubation time and $\mathrm{KH}_{2} \mathrm{PO}_{4}$ respectively. The model's significance was determined by analysis of variance; the regression equation was obtained, a $\mathrm{P}$ value less than 0.05 indicates that the model term is significant. The fit of the model (R2) was studied, and the results were closer to show a better correlation between experimental and predicted values. Moreover, a response optimizer was carried out to detect the optimum conditions for phytase production.

Table 1. Factors and their levels were chosen for Box-Behnken design.

\begin{tabular}{l|l|c|c|c}
\multirow{2}{*}{ Factors } & Name & \multicolumn{3}{|c}{ Levels } \\
\cline { 3 - 5 } X1 & Potato peel conc. (\%) & -1 & 0 & +1 \\
\hline $\mathrm{X} 2$ & Incubation time (Days) & 1 & 1.5 & 2 \\
\hline $\mathrm{X} 3$ & $\mathrm{KH}_{2} \mathrm{PO}_{4}(\mathrm{~g} / \mathrm{l})$ & 5 & 6 & 7 \\
\hline
\end{tabular}

\subsection{Partial purification of phytase.}

The crude phytase enzyme was partially purified by precipitation of ammonium sulfate to $80 \%$ saturation. The precipitated phytase was collected using centrifugation at $10,000 \mathrm{rpm}$ for $10 \mathrm{~min}$ at $4^{\circ} \mathrm{C}$ and dissolved in a minimum volume of acetate buffer $(0.2 \mathrm{M} ; \mathrm{pH} 5.5)$. The solution of the enzyme was dialyzed at $4{ }^{\circ} \mathrm{C}$ against the buffer for $24 \mathrm{~h}$. The dialysis was concentrated through a freeze dryer and dissolved in a minimum volume of the buffer. Then, phytase activity was estimated.

\subsection{Characterization of partially purified phytase.}

The enzyme precipitated by ammonium sulfate and desalted by dialysis was used to characterize partially purified phytase.

\subsubsection{Effect of different $\mathrm{pH}$ values.}

The optimum $\mathrm{pH}$ value was determined by measuring the number of partially purified phytase activities between $\mathrm{pH} 4.0$ and 7.0 using acetate buffer $0.2 \mathrm{M}(\mathrm{pH} 4-5.5)$ and phosphate buffer 0.2M (pH 6-7).

\subsubsection{Effect of different temperatures.}

For determining the optimum temperature for the activity of partially purified phytase, the enzyme assays were carried out in the temperature range between 30 and $60^{\circ} \mathrm{C}$.

\subsubsection{Effect of metal ions and surfactants.}

The influence of metal ions and surfactants on partially purified phytase activities was studied. Metal ions such as $\mathrm{KCl}, \mathrm{CaCl}_{2}, \mathrm{MgSO}_{4} .7 \mathrm{H}_{2} \mathrm{O}, \mathrm{MnCl}_{2}, \mathrm{ZnSO}_{4}, \mathrm{CuSO}_{4}, \mathrm{FeSO}_{4}$, and surfactants, i.e., Triton 100, Tween-20, and Tween-80, were added to the mixture at $(0.1 \% \mathrm{w} / \mathrm{v})$ to determine their effect on phytase activities. Then, enzyme activities were assayed. 


\subsection{Application of phytase in dyes decolorization processes.}

The partially purified phytase was applied to de-colorize two synthetic dyes (Crystal violet and Methyl red). The reaction consisted of $4 \mathrm{~mL}$ of each dye dissolved in distilled water and $1 \mathrm{~mL}$ of purified phytase in a total volume of $5 \mathrm{~mL}$. A decrease in the maximum absorbance of dyes (Crystal violet, $575 \mathrm{~nm}$, and Methyl red, $520 \mathrm{~nm}$ ) was determined every $30 \mathrm{~min}$ after incubation of reaction mixtures at $37{ }^{\circ} \mathrm{C}$. At the parallel, control without phytase was processed to confirm non-enzyme decolorization. All decolorization experiments were tested in triplicate.

\subsection{Statistical analysis.}

Means of three replicates and standard errors were calculated for all obtained results, and the data were subjected to analysis of variance means using sigma plot 12.5 programs.

\section{Results and Discussion}

\subsection{Identifications of fungal strain.}

Colonies of fungal isolate NSA20 are moderate growing and a dark grey-green, sporulation moderately dense, conidiophores biverticillate, subterminal branches absent; stipes smooth-walled, phialides acerose, 3-5 per metula, conidia smooth, ellipsoidal Figure 1A. The $18 \mathrm{~S}$ rRNA gene analysis of the fungal isolate NSA20 showed similarity (98.56\%) with Talaromyces purpurogenus, as shown in a phylogenetic tree Figure 1B. The Gen Bank accession number for strain NSA20 nucleotide sequence is MW031769.1, identified as Talaromyces purpurogenum NSA20.

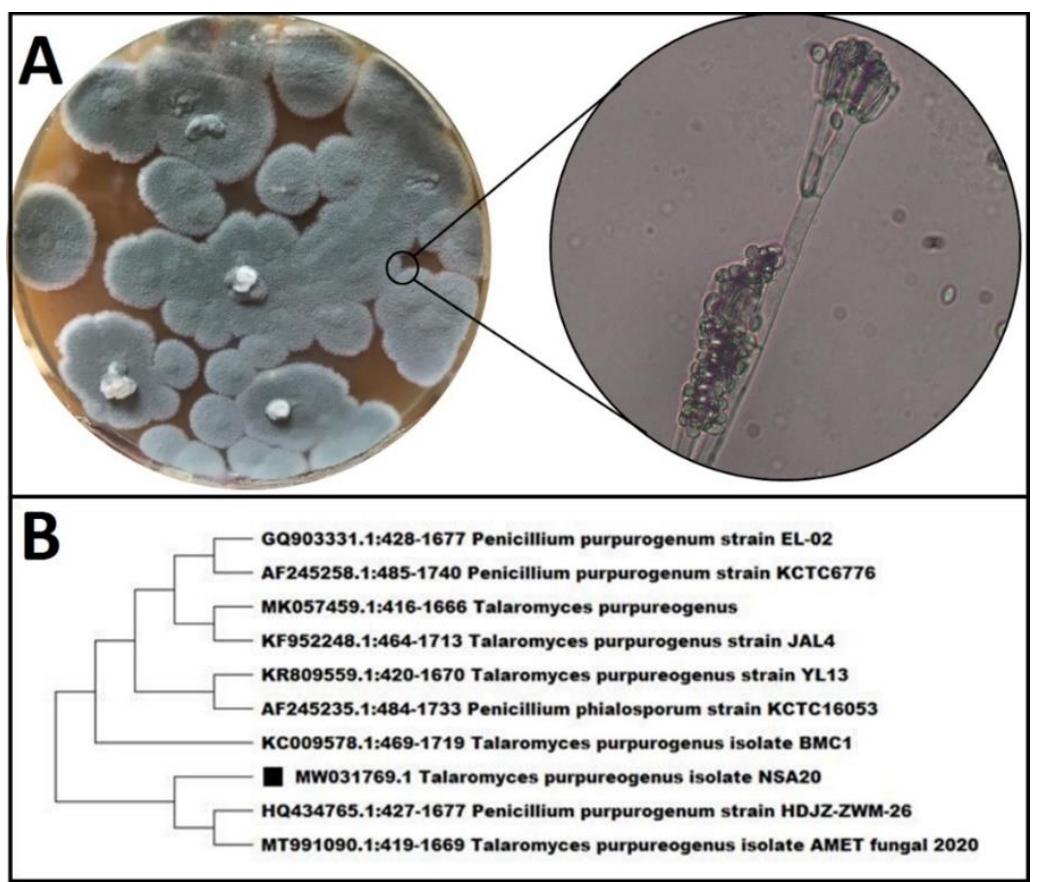

Figure 1. Identification of fungal strain NSA20 (A-B): A) Morphological identification. B) Neighbor-Joining phylogenetic tree of $18 \mathrm{~s}$ rRNA gene.

\subsection{Phytase production by T. purpureogenus NSA20.}

The results showed that T. purpureogenus NSA20 was the highest for phytase production in fermentation medium $(103.5 \mathrm{U} / \mathrm{ml})$. [31] showed that $T$. lanuginosus strain 
produced the highest value of phytase (25 U/L). [32] reported that $A$. niger gave the highest level of phytase activity, $138.6 \mathrm{U} / \mathrm{mL}$. [30] indicated that $P$. purpurogenum produced a high amount of phytase $(150 \mathrm{U} / \mathrm{ml})$. Also, [33] mentioned that $A$. heteromorphus produced the highest value of phytase activity $14.80 \mathrm{U} / \mathrm{ml}$. Likewise, [34] indicated that phytase enzyme had been produced from Aspergillus oryzae.

\subsection{Effect of agricultural wastes on the production of phytase.}

The utilization of agricultural waste products is considered the main goal of many researchers to get cheap mediums and solve the problems that resulted from the accumulation of these wastes. Within this context, different agricultural wastes as wheat bran, corn cobs, rice bran, rice straw, corn starch, soybean powder, potato peel, orange peel, and peanut peel were used as a substrate for the production of phytase utilizing T. purpureogenus NSA20. Figure 2A showed that all the agriculture waste used as substrates had phytase activities despite the variety in the activity value. The highest phytase activity $(114.5 \mathrm{U} / \mathrm{ml})$ by $T$. purpureogenus NSA20 was observed when potato peel was utilized as a substrate, followed by peanut peel and orange peel produce $(99.25,97.7 \mathrm{U} / \mathrm{ml})$, respectively. While soybean powder, wheat bran, and rice bran were produced $(96.18,95.9$, and $91.14 \mathrm{U} / \mathrm{ml})$, the lowest productivity of phytase was noticed with corn cobs waste with a yield of $82.28 \mathrm{U} / \mathrm{ml}$. The results proved that the potato peel waste was a good substrate for phytase production by $T$. purpureogenus NSA20. The selection of substrate for the formation of an enzyme is a key factor and significant role in producing suitable metabolites [35]. Other results were shown by [36, 37] indicated that the phytase formation by B. cereus, P. stewartii, and Mucor jalaludinii was increased using the rice bran supplementation. Awad et al. indicated that the highest yield of the enzyme by $P$. purpurogenum GE1 fungus grown on corn cob was $46 \pm 2.8 \mathrm{U} / \mathrm{g}$ ds [30]. Others reported that the highest phytase production by $R$. oryzae fungus grown on coconut oil was $30.1 \mathrm{U} / \mathrm{gds}$ [38]. While others found that $A$. ficuumNRRL3135 had the highest productivity (15 IU phytase activity/g dry matter) on wheat bran [39]. Others reported that the phytase production by $M$. racemosus utilizing combinations of numerous oil cakes with wheat bran which gave the highest productivity of phytase $32.2 \mathrm{U} / \mathrm{gds}$ [40]. [41] studied the application of A. niger, $R$. oryzae, and Neurospora sitophila, on mixed soybean curd and rice straw. Neurospora sitophila showed the highest productivity of phytase at $195.66 \mathrm{U} / \mathrm{g}$. [31] reported that Thermomyces lanuginosus gave a high value of phytase $(25 \mathrm{U} / \mathrm{L})$ on medium containing rice flour as the main carbon source. Also, rice flour was a good carbon source for phytase formation using A. niger [42].

\subsection{Effect of potato peel concentrations on phytase production.}

The best substrate waste for the production of phytase was potato peel utilizing $T$. purpureogenus NSA20 0 . The influence of potato peel concentrations on phytase production using T. purpureogenus NSA20 was investigated. Figure 2B illustrates the high-value production of phytase $(120.3 \mathrm{U} / \mathrm{ml})$ with a waste concentration at $1.5 \% \mathrm{w} / \mathrm{v}$. Further decrease or increase in the potato peels concentration leads to decrease phytase production. Other results were reported by [31], who studied the influence of rice flour concentrations on phytase production using $T$. lanuginosus and showed the optimal rice flour concentration for maximum activity of phytase was $5 \%(\mathrm{w} / \mathrm{v})$ at 200rpm after the 4th day of fermentation. 


\subsection{Effect of incubation time on phytase production.}

The influence of incubation time on the production of phytase by T. purpureogenus NSA20 was studied. Figure 2C shows high phytase production $(138.4 \mathrm{U} / \mathrm{ml})$ was observed on the 6th day of incubation. After that, the phytase activities decreased gradually as incubation time increased due to reduced nutrient level of medium or autolysis of the mycelium occurred [43]. Singh and Satyanarayana showed that the increase in phytase production was on the fifth day of incubation by Sporotrichum thermophile [44]. Researchers have shown that the maximum production of phytase from A. niger was evaluated on the $4^{\text {th }}$ day $(38.5 \mathrm{U} / \mathrm{ml}$ in SSF and $25.6 \mathrm{U} / \mathrm{ml}$ in $\mathrm{SMF}$ ) [45]. A previous study reported that the highest value of phytase production by A. tubingensis was after 4 days using wheat bran [46]. Lata et al. mentioned that the phytase activity was initially detected at $48 \mathrm{hr}$ and increased with time [33]. A high growth level and the production of phytase $(17.88 \mathrm{U} / \mathrm{ml})$ were observed at $120 \mathrm{hrs}$ of incubation time by A. heteromorphus. However, high phytase activity $(68 \mathrm{U} / \mathrm{ml})$ was shown on the 11 th day of incubation by A. niger [47].
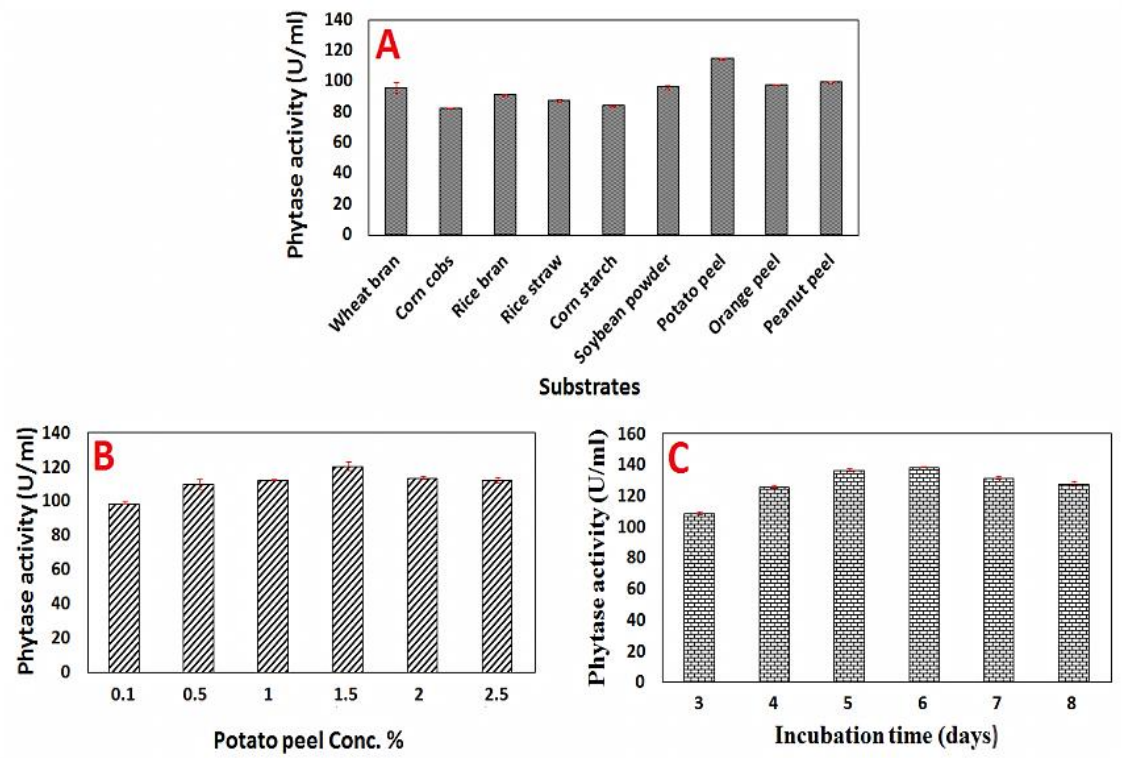

Figure 2. Influence of agricultural wastes (A), the concentration of Potato peel (B) and, incubation time (C) on phytase production by $T$. purpureogenus NSA20.

\subsection{Response surface methodology (Box-Behnken design).}

Box-Behnken design was performed to make more interactions between factors and their levels for getting the target product. Box-Behnken design is more efficient and robust than other designs as full multi-level design, central-composite design (CCD), and doehlert-design, despite its poor coverage of the angle of the nonlinear design space [48]. Table 2 illustrates Box-Behnken design which includes three factors (potato peel concentration, incubation time, and $\mathrm{KH}_{2} \mathrm{PO}_{4}$ ) with three-level for each. Results showed high phytase activity in run no. 14 with potato peel $1.5 \%$, incubation time 7 days, and $\mathrm{KH}_{2} \mathrm{PO}_{4} 1.0 \mathrm{~g} / \mathrm{l}$. The F value (Fisher's statistical analysis) and P-value (>0.0001) were used for determining the significance of the model. Low $\mathrm{P}$ values indicate the high significance of the corresponding coefficient, whereas large $\mathrm{t}$ and $\mathrm{F}$ values indicate the significance of corresponding coefficients [49]. ANOVA results showed that the model is highly significant where $\mathrm{P}$ value $<0.05$. Moreover, model terms $\mathrm{KH}_{2} \mathrm{PO}_{4}$, $\mathrm{KH}_{2} \mathrm{PO}_{4} * \mathrm{KH}_{2} \mathrm{PO}_{4}$, and Time* $\mathrm{KH}_{2} \mathrm{PO}_{4}$ were significant for phytase production, as shown in 
Table 3. The correlation coefficient (R2) measures how much the observed response variability can be explained by the experimental parameters and their interactions [50]. $\mathrm{R}^{2}$ of the model is 0.991 , which indicates that $99.10 \%$ of the variability in the response could be expressed by the model. The production of phytase activity $(\mathrm{U} / \mathrm{ml})$ was predicted by the following model equation:

Phytase activity $=-387+168.2 \mathrm{X}_{1}+119.4 \mathrm{X}_{2}+220.9 \mathrm{X}_{3}-36.0\left(\mathrm{X}_{1} * \mathrm{X}_{1}\right)-9.32\left(\mathrm{X}_{2} * \mathrm{X}_{2}\right)$

$$
-223.5\left(\mathrm{X}_{3} * \mathrm{X}_{3}\right)-8.25\left(\mathrm{X}_{1} * \mathrm{X}_{2}\right)-13.3\left(\mathrm{X}_{1} * \mathrm{X}_{3}\right)+21.80\left(\mathrm{X}_{2} * \mathrm{X}_{3}\right) \text {. }
$$

Table 4 shows $\mathrm{KH}_{2} \mathrm{PO}_{4}$ only factor had a significant effect on phytase activity. While as potato peel and incubation time factors had no significant effect on phytase production. Moreover, all interactions had no significant effect except potato peel and $\mathrm{KH}_{2} \mathrm{PO}_{4}$, as shown in Figure 3. The optimal levels of the three components as obtained from the maximum point of the polynomial model were estimated using response optimizer in Mini tab 17 software and found to be: potato peel $1.42 \mathrm{~g} / \mathrm{l}$, incubation time $6.67 \mathrm{~d}(160.08 \mathrm{~h})$, and $\mathrm{KH}_{2} \mathrm{PO}_{4} 0.778 \mathrm{~g} / \mathrm{l}$ with a predicted phytase activity of $217.36 \mathrm{U} / \mathrm{l}$. Finally, this statistical analysis revealed that the optimized medium for phytase production increased to 1.57 fold compared to one factor at a time (OFAT) optimized medium.

Table 2. Effect of different parameters on phytase production using Box-Behnken design.

\begin{tabular}{|c|c|c|c|c|c|c|}
\hline \multirow[t]{2}{*}{ Run } & \multirow{2}{*}{$\begin{array}{c}\text { Potato peel concentration } \\
(\%)\end{array}$} & \multirow[t]{2}{*}{ Incubation time (Days) } & \multirow{2}{*}{$\begin{array}{c}\mathrm{KH}_{2} \mathrm{PO}_{4} \\
(\mathrm{~g} / \mathrm{l})\end{array}$} & \multicolumn{3}{|c|}{ Phytase activity (U/ml) } \\
\hline & & & & Actual & Predicted & Residual \\
\hline 1 & 1.0 & 5 & 0.5 & 168 & 169.881 & -1.88125 \\
\hline 2 & 2.0 & 5 & 0.5 & 180.8 & 182.244 & -1.44375 \\
\hline 3 & 2.0 & 6 & 0.0 & 92.83 & 86.885 & 5.94500 \\
\hline 4 & 2.0 & 7 & 0.5 & 188 & 186.119 & 1.88125 \\
\hline 5 & 1.5 & 6 & 0.5 & 200.2 & 200.433 & -0.233333 \\
\hline 6 & 1.0 & 6 & 0.0 & 82.48 & 76.0975 & 6.38250 \\
\hline 7 & 1.5 & 5 & 0.0 & 81.5 & 86.0012 & -4.50125 \\
\hline 8 & 1.0 & 6 & 1.0 & 185 & 190.945 & -5.94500 \\
\hline 9 & 1.5 & 6 & 0.5 & 200.9 & 200.433 & 0.466667 \\
\hline 10 & 1.5 & 5 & 1.0 & 180.2 & 172.374 & 7.82625 \\
\hline 11 & 2.0 & 6 & 1.0 & 182 & 188.382 & -6.38250 \\
\hline 12 & 1.0 & 7 & 0.5 & 191.7 & 190.256 & 1.44375 \\
\hline 13 & 1.5 & 6 & 0.5 & 200.2 & 200.433 & -0.233333 \\
\hline 14 & 1.5 & 7 & 1.0 & 210.8 & 206.299 & 4.50125 \\
\hline 15 & 1.5 & 7 & 0.0 & 68.5 & 76.3262 & -7.82625 \\
\hline
\end{tabular}

Table 3. Analysis of variance for Box-Behnken design.

\begin{tabular}{l|l|l|l|l|l} 
Source & Degree of freedom & Sum of squares & Mean of squares & F-value & P-value \\
\hline Model & 9 & 36005.5 & 4000.6 & 61.22 & 0.000 \\
\hline$X_{1}$ & 1 & 33.8 & 33.8 & 0.52 & 0.504 \\
\hline$X_{2}$ & 1 & 294.0 & 294.0 & 4.50 & 0.087 \\
\hline$X_{3}$ & 1 & 23402.6 & 23402.6 & 358.11 & 0.000 \\
\hline$X_{I}^{2}$ & 1 & 298.4 & 298.4 & 4.57 & 0.086 \\
\hline$X_{2}^{2}$ & 1 & 320.6 & 320.6 & 4.91 & 0.078 \\
\hline$X_{3}^{2}$ & 1 & 11523.5 & 11523.5 & 176.33 & 0.000 \\
\hline$X_{1} X_{2}$ & 1 & 68.1 & 68.1 & 1.04 & 0.354 \\
\hline$X_{1} X_{3}$ & 1 & 44.6 & 44.6 & 0.68 & 0.447 \\
\hline$X_{2} X_{3}$ & 1 & 475.2 & 475.2 & 7.27 & 0.043 \\
\hline Lack-of-Fit & 3 & 326.4 & 108.8 & 666.18 & 0.001 \\
\hline Pure Error & 2 & 0.3 & 0.3 & &
\end{tabular}

A value of $P<0.05$ indicates that the model term is significant. $R^{2}=0.9910 \% \quad$ Adj $R^{2}=0.9748$

Table 4. Regression analysis of a full second-order polynomial model for optimization of phytase production.

\begin{tabular}{l|c|c|c|c} 
Term & Coefficient & Standard error of coefficient & T-Value & P-Value \\
\hline Intercept & 200.43 & 4.67 & 42.94 & 0.000 \\
\hline$X_{I}$ & 2.06 & 2.86 & 0.72 & 0.504 \\
\hline$X_{2}$ & 6.06 & 2.86 & 2.12 & 0.087 \\
\hline$X_{3}$ & 54.09 & 2.86 & 18.92 & 0.000 \\
\hline$X_{I^{2}}$ & -8.99 & 4.21 & -2.14 & 0.086
\end{tabular}




\begin{tabular}{l|c|c|c|c} 
Term & Coefficient & Standard error of coefficient & T-Value & P-Value \\
\hline$X_{2}^{2}$ & -9.32 & 4.21 & -2.21 & 0.078 \\
\hline$X_{3}^{2}$ & -55.87 & 4.21 & -13.28 & 0.000 \\
\hline$X_{I} X_{2}$ & -4.13 & 4.04 & -1.02 & 0.354 \\
\hline$X_{1} X_{3}$ & -3.34 & 4.04 & -.083 & 0.447 \\
\hline$X_{1} X_{3}$ & 10.9 & 4.04 & 2.70 & 0.043
\end{tabular}
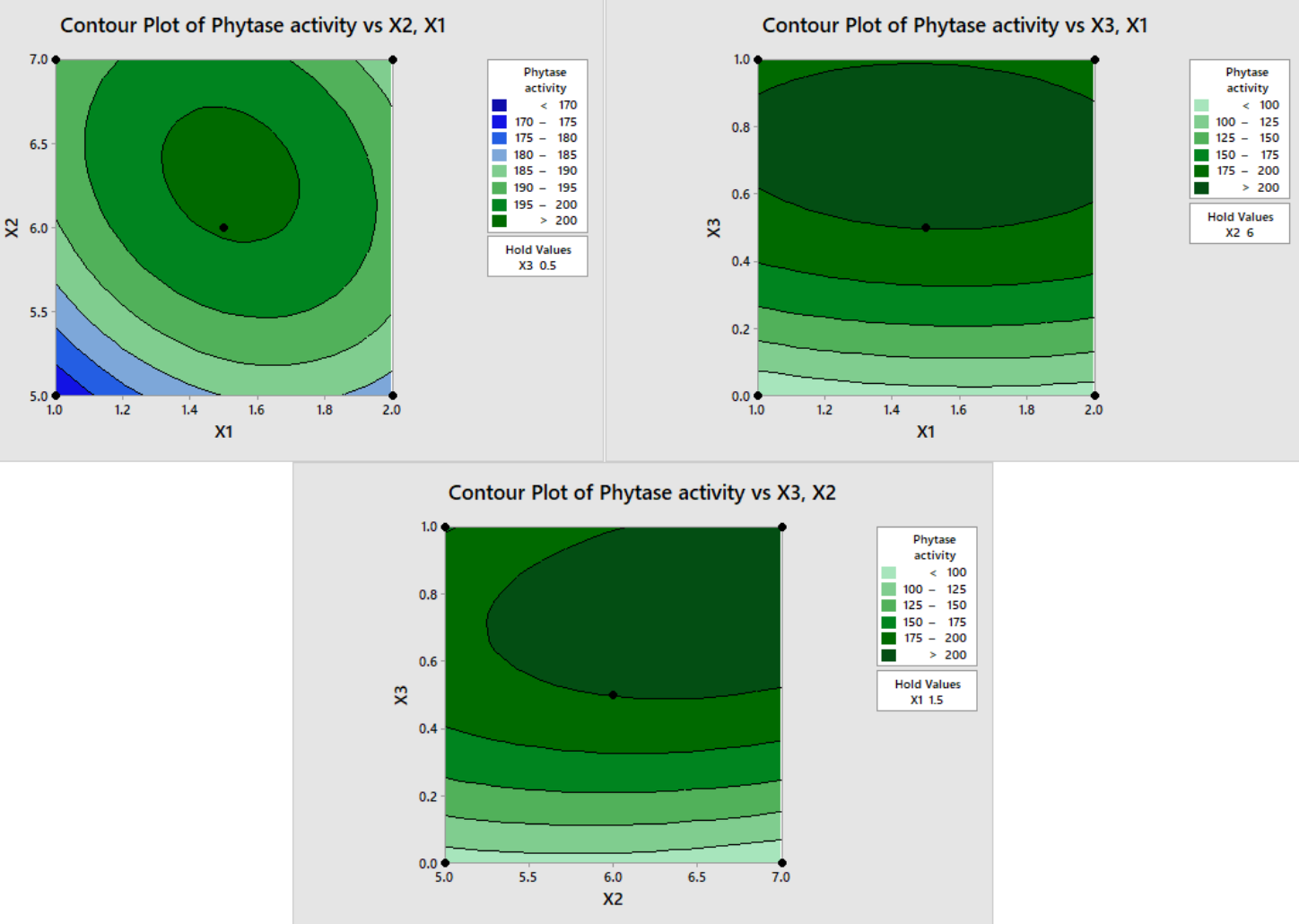

Figure 3. Contour plot of phytase activity vs. interactions between potato peel (\%), incubation time (d), and $\mathrm{KH}_{2} \mathrm{PO}_{4}(\mathrm{~g} / \mathrm{l})$.

\subsection{Partial purification of phytase.}

The crude enzyme produced from $T$. purpurogenus NSA20 using potato peel waste $1.5 \%$ was partially purified by ammonium sulfate $(80 \%)$ precipitation and dialysis. The results summarized in Table 5 recorded that the enzyme after precipitation with ammonium sulfate $(80 \%)$ was 2.6 -fold purified phytase, and the yield was $39.8 \%$., the specific activity was $31.19 \mathrm{U} / \mathrm{mg}$ protein. Ajith et al. studied that the phytase's purification from A. foetidus using ammonium sulfate followed by chromatography separation, demonstrates that phytase was purified about 23.4-fold with the recovery of $13 \%$ from the crude enzyme [51]. In a previous study reported that the phytase from $T$. lanuginosus was purified about 9.1-fold with a production of $5.1 \%$ [31]. The phytase enzyme produced from Thermomyces lanuginosus was purified, resulting in $3.44 \%$ production and 40.75 fold [52]. The higher purification fold may be due to the beginning protein synthesized on wheat bran through SSF. The ratio of phytase is lower in the crude protein, which leads lower fold.

Table 5. Partial Purification of phytase produced by T. purpureogenus NSA20.

\begin{tabular}{|c|c|c|c|c|c|}
\hline Purification steps & Total activity (U/ml) & Total protein (mg) & $\begin{array}{c}\text { Specific activity } \\
(\mathrm{U} / \mathbf{m g})\end{array}$ & $\begin{array}{c}\% \\
\text { Yield }\end{array}$ & Fold \\
\hline Crude enzyme & 5270 & 432.5 & 12.18 & 100 & 1 \\
\hline $\begin{array}{l}\text { Precipitation with ammonium } \\
\text { sulfate }(80 \%)\end{array}$ & 2096 & 67.2 & 31.19 & 39.8 & 2.6 \\
\hline After dialysis & 627.5 & 8.75 & 71.7 & 11.9 & 5.9 \\
\hline
\end{tabular}


3.8. Characterization of partially purified phytase.

3.8.1. Effect of different $\mathrm{pH}$ values.

Effect of $\mathrm{pH}$ on phytase activity produced from $T$. purpureogenus NSA20 at $\mathrm{pH}$ range from (4-7) was observed in Figure 4A. The maximum activity of phytase at $\mathrm{pH}$ 5.5, other results were reported that the high activities of phytase at $\mathrm{pH} 3.5,5.4$, and $5.5[51,53]$. The optimium $\mathrm{pH}$ was 5.5 in the case of phytase originated from thermophilic-fungi A. fumigatus, $M$. thermophile, and $S$. thermophile [54]. The $\mathrm{pH}$ optimum at phytase from Thermomyces lanuginosus and $T$. aurantiacus was at pH $5.0[42,55]$.

\subsubsection{Effect of different temperatures.}

The influence of temperatures on phytase activity produced from $T$. purpureogenus NSA20 was studied in the range from 30 to $70^{\circ} \mathrm{C}$. Figure 4B reported that the highest value of the activity of phytase was observed at $37^{\circ} \mathrm{C}$. Another result was reported by [51], who studied the influence of temperature on phytase activity from $A$. foetidus and appeared activities in the range $4-80{ }^{\circ} \mathrm{C}$ with high activity at $37{ }^{\circ} \mathrm{C}$. A previous study mentioned that the optimum temperature of phytase produced from $T$. lanuginosus was measured at $70^{\circ} \mathrm{C}$ [26]. The phytase produced from $A$. niger appeared a high value of specific activities at temperatures ranged from $52-55^{\circ} \mathrm{C}[56]$.

\subsubsection{Effect of metal ions and detergents.}

The effects of metal ions and detergents on phytase activities were investigated by adding various salts and detergents to the reaction mixture at $(0.1 \% \mathrm{w} / \mathrm{v})$. The results recorded in Figure $4 \mathrm{C}$ reported that ion $\mathrm{Fe}^{++} 0.1 \%$ increased the activities of phytase with $6 \%$,
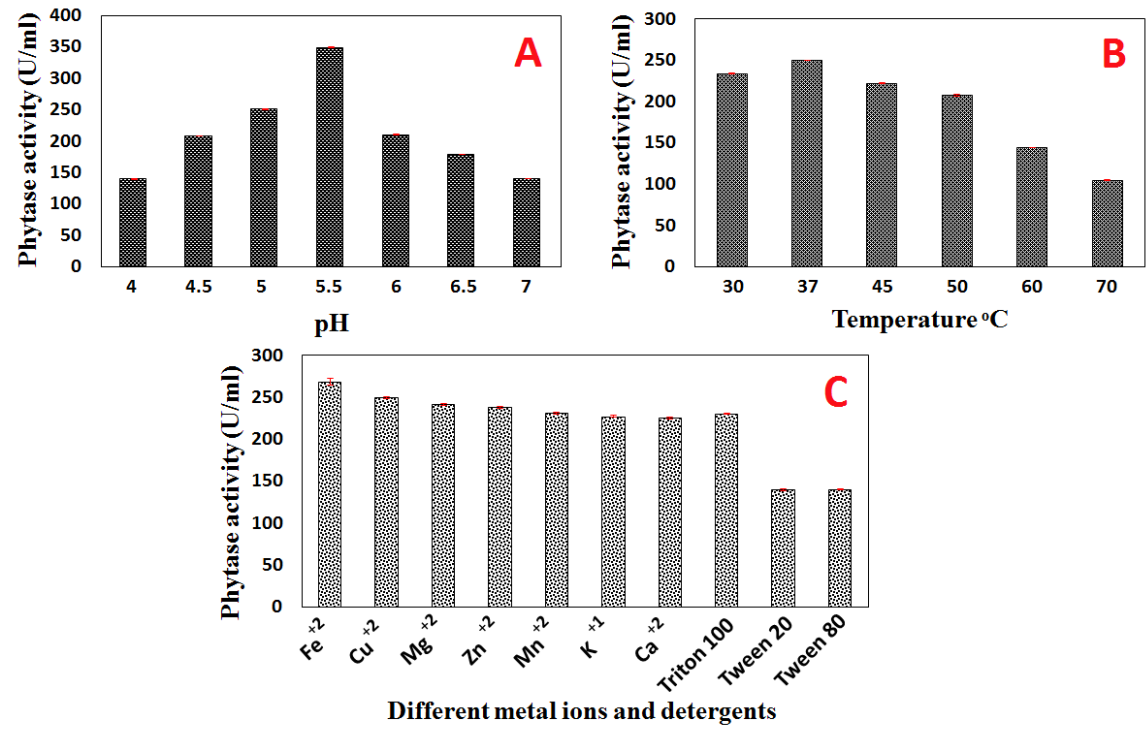

Figure 4. Influence of $\mathrm{pH}(\mathrm{A})$, temperature (B), and metal ions and detergents (C) on phytase activity from $T$. purpureogenus NSA20.

However the metal ions $\mathrm{Ca}^{++}, \mathrm{K}^{+}, \mathrm{Mg}^{++}, \mathrm{Mn}^{++}, \mathrm{Cu}^{++}$and $\mathrm{Zn}^{++}$not effect on activities. The phytase was more resistant to inactivation by metal ions: The detergents Triton -100 at $0.1 \%$ showed no effect on phytase activity, while Tween-20 and Tween-80 at $1 \%$ showed inhibitory effects on the phytase activity (44.3\%). [31] reported that the presence of $1 \mathrm{mM}$ 
$\mathrm{Fe}^{3+}, \mathrm{Fe}^{2+}$, and $5 \mathrm{mM} \mathrm{Ca}^{2+}, \mathrm{Mg}^{2+}$ and $\mathrm{K}^{+}$, ions resulted in $13-22 \%$ increase yield of activity, whereas the presence of $5 \mathrm{mM}$ of $\mathrm{Ag}^{+}, \mathrm{Co}^{2+}$ and $\mathrm{Zn}^{2+}$, ions resulted from an inhibitory effect on phytase activity of $T$. lanuginosus. $\mathrm{Na}^{+}$ion does not affect on phytase activity of $T$. lanuginosus. Gulati et al. reported that $\mathrm{Cu}^{2+}$ ion has an inhibitory effect on phytase produced from T. lanuginosus strain, but each of $\mathrm{Ca}^{2+}, \mathrm{Mg}^{2+}, \mathrm{Fe}^{2+}, \mathrm{K}^{+}, \mathrm{Mn}^{2+}, \mathrm{Na}^{+}, \mathrm{Ba}^{+}, \mathrm{Zn}^{2+}$ ions decrease the phytase activity in a concentration of $5 \mathrm{mM}$ [52]. $\mathrm{Cu}^{2+}$ ions at $1 \mathrm{mM}$ inhibited phytase produced from Neurospora crassa, and $\mathrm{Ca}^{2+}, \mathrm{Mg}^{2+}, \mathrm{Fe}^{2+}, \mathrm{Co}^{2+}, \mathrm{Mn}^{2+}, \mathrm{Zn}^{2+}$ ions have no significant effect on phytase activity [57]. Others reported that the $\mathrm{Fe}^{2+}$ and $\mathrm{Fe}^{3+}$ ions have an inhibitory effect at $1 \mathrm{mM}$ on phytase formation by E. nidulans, A. terreus, A. niger, and A. fumigatus [58].

\subsection{Dye decolorization by phytase.}

The partially purified phytase from optimized was applied to de-colorize two synthetic dyes; Crystal violet and Methyl red. The decolorization percentage of two dyes was increased by increasing gradually in time and appeared its high effect after 120min Figure 5 . The results showed that decolorization percentages of the Crystal violet and Methyl red dyes by partially purified phytase were $85.5 \%$ and $75 \%$, respectively, after 120 min incubation, as shown in Figure 5. Aghaie-Khouzani et al. optimized and purified enzyme from the culture of $P$. variabile and evaluated its utilized in decolorization of Sudan black, Amido Black, Crystal violet, Rimazol brilliant blue, and Bromothymol blue; the data appeared that the decolorization of five dyes were 84, 54, 94, 93 and 87\% respectively, after 180 min [59]. Another study utilized the fungal cells of Aspergillus niger to decolorization of azo dyes (Reactive red (4BL) and Reactive yellow (4GL), the decolorization percentage was $92.42 \%$ and $98.62 \%$, respectively on shaker after 7 days [60].

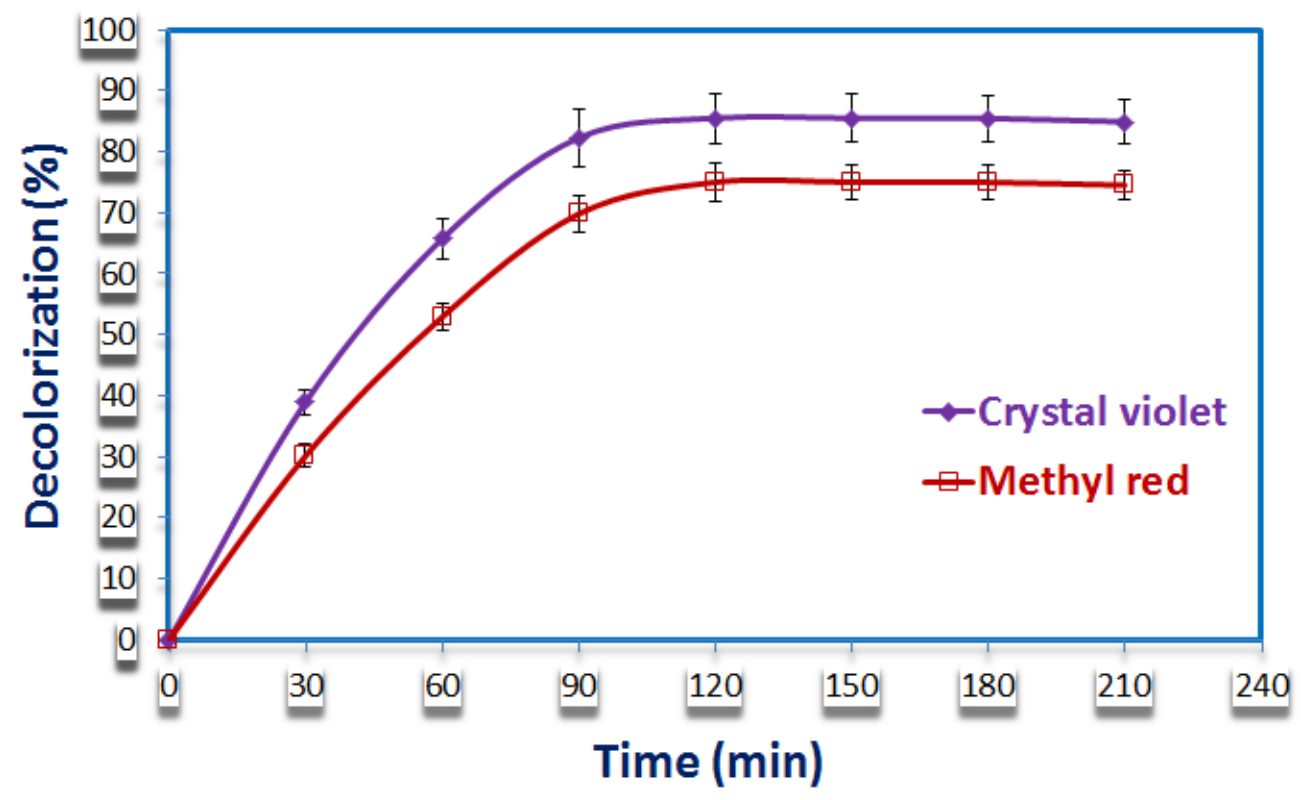

Figure 5. Dye decolorization using partially purified phytase from T. purpureogenus NSA20.

\section{Conclusions}

A promising T. purpureogenus NSA20 as a phytase-producing marine fungal strain was isolated and identified genetically in the current study. Results revealed that potato peel waste as a substrate for T. purpureogenus NSA20 is the highest for phytase production among other 
wastes. Statistical optimization using Box-Behnken design as response surface methodology was carried out, where statistical analysis illustrated that optimized medium for phytase production increased to 1.57 fold compared to OFAT optimized medium. Moreover, partial purification of crude enzyme and characterization of partially purified phytase was performed. Finally, partially purified phytase was effective for decolorizing crystal violet and methyl red quickly.

\section{Funding}

This research received no external funding.

\section{Acknowledgments}

The authors express their sincere thanks to the Faculty of Science (Boyes), Al-Azhar University, Cairo, Egypt, for providing the necessary research facilities. The authors would like to acknowledge the facilities available at the National Research Centre of Egypt.

\section{Conflicts of Interest}

The authors declare no conflict of interest.

\section{References}

1. Raboy, V.; Gibson, R.S.; Bailey, K.B.; King, J.C. Comparison of four methods for phytate analysis in plantbased foods. Journal of Food Composition and Analysis 2020, 90, https://doi.org/10.1016/j.jfca.2020.103481.

2. Cominelli, E.; Pilu, R.; Sparvoli, F. Phytic Acid and Transporters: What Can We Learn from low phytic acid Mutants? Plants 2020, 9, https://doi.org/10.3390/plants9010069.

3. Wang, R.; Guo, S. Phytic acid and its interactions: Contributions to protein functionality, food processing, and safety. Comprehensive Reviews in Food Science and Food Safety 2021, https://doi.org/10.1111/15414337.12714.

4. Raboy, V. Low phytic acid Crops: Observations Based on Four Decades of Research. Plants 2020, 9, https://doi.org/10.3390/plants9020140.

5. Kumar, V.; Sinha, A.K. Chapter 3-General aspects of phytases. In: Enzymes in Human and Animal Nutrition. Nunes, C.S.; Kumar, V. Eds. Academic Press: 2018; 53-72, https://doi.org/10.1016/B978-0-12-8054192.00003-4.

6. Cowieson, A.J.; Acamovic, T.; Bedford, M.R. Phytic Acid and Phytase: Implications for Protein Utilization by Poultry. Poultry Science 2006, 85, 878-885, https://doi.org/10.1093/ps/85.5.878.

7. Kies, A.K.; De Jonge, L.H.; Kemme, P.A.; Jongbloed, A.W. Interaction between Protein, Phytate, and Microbial Phytase. In Vitro Studies. Journal of Agricultural and Food Chemistry 2006, 54, 1753-1758, https://doi.org/10.1021/jf0518554.

8. Soni, S.K.; Magdum, A.; Khire, J.M. Purification and characterization of two distinct acidic phytases with broad $\mathrm{pH}$ stability from Aspergillus niger NCIM 563. World Journal of Microbiology and Biotechnology 2010, 26, 2009-2018, https://doi.org/10.1007/s11274-010-0385-8.

9. Balwani, I.; Chakravarty, K.; Gaur, S. Role of phytase producing microorganisms towards agricultural sustainability. Biocatalysis and Agricultural Biotechnology 2017, 12, 23-29, https://doi.org/10.1016/j.bcab.2017.08.010.

10. Handa, V.; Sharma, D.; Kaur, A.; Arya, S.K. Biotechnological applications of microbial phytase and phytic acid in food and feed industries. Biocatalysis and Agricultural Biotechnology 2020, 25, https://doi.org/10.1016/j.bcab.2020.101600.

11. Jatuwong, K.; Suwannarach, N.; Kumla, J.; Penkhrue, W.; Kakumyan, P.; Lumyong, S. Bioprocess for Production, Characteristics, and Biotechnological Applications of Fungal Phytases. Frontiers in Microbiology 2020, 11, https://doi.org/10.3389/fmicb.2020.00188.

12. Kalkan, S.O.; Bozcal, E.; Hames Tuna, E.E.; Uzel, A. Characterisation of a thermostable and proteolysis resistant phytase from Penicillium polonicum MF82 associated with the marine sponge Phorbas sp. Biocatalysis and Biotransformation 2020, 38, 469-479, https://doi.org/10.1080/10242422.2020.1785434. 
13. Tawfik, S.; Abd Elsalam, S.; Nassar, S.; Sehata, I.; Elshemy, N.; El-Thalouth, A. Microwave assisted chemical modification of starch in presence or absence of amylase enzyme and its application in textile printing. Lett Appl NanoBioScience 2019, 8, 762-769, https://doi.org/10.33263/LIANBS84.762769.

14. Punvichai, T.; Pioch, D. Co-valorization of agro-industry by-products: effect of citrus oil on the quality of soap derived from palm fatty acid distillate and spent bleaching clay. Letters in Applied NanoBioScience 2019, 8, 571-575, https://doi.org/10.33263/LIANBS83.571575.

15. Dailin, D.J.; Hanapi, S.Z.; Elsayed, E.A.; Sukmawati, D.; Azelee, N.I.W.; Eyahmalay, J.; Siwapiragam, V.; El Enshasy, H. Fungal Phytases: Biotechnological Applications in Food and Feed Industries. In: Recent Advancement in White Biotechnology Through Fungi: Volume 2: Perspective for Value-Added Products and Environments. Yadav, A.N.; Singh, S.; Mishra, S.; Gupta, A. Eds. Springer International Publishing: Cham, 2019; pp. 65-99, https://doi.org/10.1007/978-3-030-14846-1_2.

16. Ribeiro Corrêa, T.L.; de Queiroz, M.V.; de Araújo, E.F. Cloning, recombinant expression and characterization of a new phytase from Penicillium chrysogenum. Microbiological Research 2015, 170, 205212, https://doi.org/10.1016/j.micres.2014.06.005.

17. Gaind, S.; Singh, S. Production, purification and characterization of neutral phytase from thermotolerant Aspergillus flavus ITCC 6720. International Biodeterioration \& Biodegradation 2015, 99, 15-22, https://doi.org/10.1016/j.ibiod.2014.12.013.

18. Hasanin, M.S.; Hashem, A.H.; Abd El-Sayed, E.S.; El-Saied, H. Green ecofriendly bio-deinking of mixed office waste paper using various enzymes from Rhizopus microsporus AH3: efficiency and characteristics. Cellulose 2020, 1-11, https://doi.org/10.1007/s10570-020-03071-3.

19. Selim, M.T.; Salem, S.S.; Mohamed, A.A.; El-Gamal, M.S.; Awad, M.F.; Fouda, A. Biological Treatment of Real Textile Effluent Using Aspergillus flavus and Fusarium oxysporium and Their Consortium along with the Evaluation of Their Phytotoxicity. J. Fungi 2021, 7, 193. https://doi.org/10.3390/jof7030193

20. Hashem, A.H.; Khalil, A.M.A.; Reyad, A.M.; Salem, S.S. Biomedical Applications of Mycosynthesized Selenium Nanoparticles Using Penicillium expansum ATTC 36200. Biol Trace Elem Res 2021, https://doi.org/10.1007/s12011-020-02506-z.

21. Mohamed, A.A.; Abu-Elghait, M.; Ahmed, N.E.; Salem, S.S. Eco-friendly Mycogenic Synthesis of ZnO and $\mathrm{CuO}$ Nanoparticles for In Vitro Antibacterial, Antibiofilm, and Antifungal Applications. Biol Trace Elem Res 2020, https://doi.org/10.1007/s12011-020-02369-4.

22. Shaheen, Th.I.; Fouda, A.; Salem, S.S. Integration of Cotton Fabrics with Biosynthesized CuO Nanoparticles for Bactericidal Activity in the Terms of Their Cytotoxicity Assessment. Ind. Eng. Chem. Res 2021, 60, 4, 1553-1563, https://doi.org/10.1021/acs.iecr.0c04880.

23. Abu-Elghait, M.; Hasanin, M.; Hashem, A.H.; Salem, S.S. Ecofriendly novel synthesis of tertiary composite based on cellulose and myco-synthesized selenium nanoparticles: Characterization, antibiofilm and biocompatibility. International Journal of Biological Macromolecules 2021, 175, 294-303, https://doi.org/10.1016/j.ijbiomac.2021.02.040.

24. Liu, N.; Ru, Y.; Wang, J.; Xu, T. Effect of dietary sodium phytate and microbial phytase on the lipase activity and lipid metabolism of broiler chickens. British Journal of Nutrition 2009, 103, 862-868, https://doi.org/10.1017/S0007114509992558.

25. Kennedy, M.; Krouse, D. Strategies for improving fermentation medium performance: a review. Journal of Industrial Microbiology and Biotechnology 1999, 23, 456-475, https://doi.org/10.1038/sj.jim.2900755.

26. Singh, B.; Satyanarayana, T. A marked enhancement in phytase production by a thermophilic mould Sporotrichum thermophile using statistical designs in a cost-effective cane molasses medium. Journal of Applied Microbiology 2006, 101, 344-352, https://doi.org/10.1111/j.1365-2672.2006.02921.x.

27. Fouda, A.; Khalil, A.; El-Sheikh, H.; Abdel-Rhaman, E.; Hashem, A. Biodegradation and detoxification of bisphenol-A by filamentous fungi screened from nature. J. Adv. Biol. Biotechnol 2015, 2, 123-132, https://doi.org/10.9734/JABB/2015/13959.

28. Khalil, A.M.A.; Hashem, A.H. Morphological Changes of Conidiogenesis in Two Aspergillus Species. J. Pure Appl. Microbiol. 2018, 12, 2041-2049, http://dx.doi.org/10.22207/JPAM.12.4.40.

29. Khalil, A.M.A.; Hashem, A.H.; Abdelaziz, A.M. Occurrence of toxigenic Penicillium polonicum in retail green table olives from the Saudi Arabia market. Biocatal. Agri. Biotechnol. 2019, 21, https://doi.org/10.1016/j.bcab.2019.101314.

30. Awad, G.E.A.; Helal, M.M.I.; Danial, E.N.; Esawy, M.A. Optimization of phytase production by Penicillium purpurogenum GE1 under solid state fermentation by using Box-Behnken design. Saudi J Biol Sci 2014, 21, 81-88, https://doi.org/10.1016/j.sjbs.2013.06.004.

31. Bujna, E.; Rezessy-Szabo, J.; Nguyen, D.; Nguyen, D. Production and some properties of extracellular phytase from Thermomyces lanuginosus IMI 096218 on rice flour as substrate. Mycosphere 2016, 7, 15761587, https://doi.org/10.5943/mycosphere/si/3b/9.

32. Monteiro, P.S.; Guimarães, V.M.; Melo, R.R.d.; Rezende, S.T.d. Isolation of a thermostable acid phytase from Aspergillus niger UFV-1 with strong proteolysis resistance. Brazilian Journal of Microbiology 2015, 46, 251-260, https://doi.org/10.1590/S1517-838220120037.

33. Lata, S.; Rastogi, S.; Kapoor, A.; Imran, M. Optimization of culture conditions for the production of phytase from Aspergillus heteromorphus MTCC 10685. Int J Adv Biotechnol Res 2013, 4, 224-235. 
34. Rani, R.; Ghosh, S. Production of phytase under solid-state fermentation using Rhizopus oryzae: Novel strain improvement approach and studies on purification and characterization. Bioresource Technology 2011, 102, 10641-10649, https://doi.org/10.1016/j.biortech.2011.08.075.

35. Sweetlove, L.J.; Fernie, A.R. The role of dynamic enzyme assemblies and substrate channelling in metabolic regulation. Nature Communications 2018, 9, https://doi.org/10.1038/s41467-018-04543-8.

36. Lan, G.Q.; Abdullah, N.; Jalaludin, S.; Ho, Y.W. Optimization of carbon and nitrogen sources for phytase production by Mitsuokella jalaludinii, a new rumen bacterial species. Letters in Applied Microbiology 2002, 35, 157-161, https://doi.org/10.1046/j.1472-765X.2002.01153.x.

37. Anis Shobirin Meor, H.; Abd-ElAziem, F.; Ali, A.M.; Greiner, R. Production of Phytate-Degrading Enzyme from Malaysian Soil Bacteria Using Rice Bran Containing Media. Journal Of Agrobiotechnology 2011, 1.

38. Ramachandran, S.; Roopesh, K.; Nampoothiri, K.M.; Szakacs, G.; Pandey, A. Mixed substrate fermentation for the production of phytase by Rhizopus spp. using oilcakes as substrates. Process Biochemistry 2005, 40, 1749-1754, https://doi.org/10.1016/j.procbio.2004.06.040.

39. Bogar, B.; Szakacs, G.; Linden, J.C.; Pandey, A.; Tengerdy, R.P. Optimization of phytase production by solid substrate fermentation. Journal of Industrial Microbiology and Biotechnology 2003, 30, 183-189, https://doi.org/10.1007/s10295-003-0027-3.

40. Roopesh, K.; Ramachandran, S.; Nampoothiri, K.M.; Szakacs, G.; Pandey, A. Comparison of phytase production on wheat bran and oilcakes in solid-state fermentation by Mucor racemosus. Bioresource Technology 2006, 97, 506-511, https://doi.org/10.1016/j.biortech.2005.02.046.

41. Kanti, A.; Sudiana, I.M. Production of Phytase, Amylase and Cellulase by Aspergillus, Rhizophus and Neurospora on Mixed Rice Straw Powder and Soybean Curd Residue. IOP Conference Series: Earth and Environmental Science 2018, 166, https://doi.org/10.1088/1755-1315/166/1/012010.

42. Bujna, E.; Kukovics, F.; Nguyen, Q.; Rezessy-Szabó, J. Rice flour as potential carbon source for production of phytase by Aspergillus niger F00735 strain. Acta Alimentaria 2013, 42, 1-9, https://doi.org/10.1556/aalim.42.2013.suppl.1.

43. Muller dos Santos, M.; Souza da Rosa, A.; Dal'Boit, S.; Mitchell, D.A.; Krieger, N. Thermal denaturation: is solid-state fermentation really a good technology for the production of enzymes? Bioresource Technology 2004, 93, 261-268, https://doi.org/10.1016/j.biortech.2003.11.007.

44. Singh, B.; Satyanarayana, T. Production of phytate-hydrolyzing enzymes by thermophilic moulds. African Journal of Biotechnology 2012, 11, 12314-12324.

45. Sandhya, A.; Sridevi, A.; Narasimha, G. Production and optimization of phytase by Aspergillus niger. Der Pharmacia Lettre 2015, 7 148-153.

46. Qasim, S.S.; Shakir, K.A.; Al-Shaibani, A.B.; Walsh, M.K. Optimization of Culture Conditions to Produce Phytase from \&lt;i\&gt;Aspergillus tubingensis SKA\&lt;/i\&gt. Food and Nutrition Sciences 2017, 8, https://doi.org/10.4236/fns.2017.87052.

47. Bhavsar, K.; Shah, P.; Soni, S.K.; Khire, J. Influence of pretreatment of agriculture residues on phytase production by Aspergillus niger NCIM 563 under submerged fermentation conditions. African Journal of Biotechnology 2008, 7 .

48. Karmoker, J.R.; Hasan, I.; Ahmed, N.; Saifuddin, M.; Reza, M.S. Development and Optimization of Acyclovir Loaded Mucoadhesive Microspheres by Box-Behnken Design. Dhaka University Journal of Pharmaceutical Sciences 2019, 18, 1-12, https://doi.org/10.3329/dujps.v18i1.41421.

49. Salihu, A.; Alam, Z.; AbdulKarim, I.; Salleh, H.M. Evaluation of nutritional components by PlackettBurman design for Penicillium citrinum lipase production using palm oil mill effluent. African Journal of Biotechnology 2011, 10, 18704-18708.

50. Reddy, L.; Wee, Y.-J.; Yun, J.-S.; Ryu, H.-W. Optimization of alkaline protease production by batch culture of Bacillus sp. RKY3 through Plackett-Burman and response surface methodological approaches. Bioresource technology 2008, 99, 2242-2249, https://doi.org/10.1016/j.biortech.2007.05.006.

51. Ajith, S.; Ghosh, J.; Shet, D.; ShreeVidhya, S.; Punith, B.; Elangovan, A. Partial purification and characterization of phytase from Aspergillus foetidus MTCC 11682. AMB Express 2019, 9, 1-11, https://doi.org/10.1186/s13568-018-0725-X.

52. Gulati, H.; Chadha, B.; Saini, H. Production, purification and characterization of thermostable phytase from thermophilic fungus Thermomyces lanuginosus TL-7. Acta Microbiologica et Immunologica Hungarica 2007, 54, 121-138, https://doi.org/10.1556/AMicr.54.2007.2.3.

53. Chadha, B.S.; Harmeet, G.; Mandeep, M.; Saini, H.S.; Singh, N. Phytase production by the thermophilic fungus Rhizomucor pusillus. World Journal of Microbiology and Biotechnology 2004, 20, 105-109, https://doi.org/10.1023/B:WIBI.0000013319.13348.0a.

54. Wang, Y.; Gao, X.; Su, Q.; Wu, W.; An, L. Cloning, Expression, and Enzyme Characterization of an Acid Heat-Stable Phytase from Aspergillus fumigatus WY-2. Current Microbiology 2007, 55, https://doi.org/10.1007/s00284-006-0613-5.

55. Nampoothiri, K.M.; Tomes, G.J.; Roopesh, K.; Szakacs, G.; Nagy, V.; Soccol, C.R.; Pankey, A. Thermostable phytase production by Thermoascus aurantiacus in submerged fermentation. Applied Biochemistry and Biotechnology 2004, 118, 205-214, https://doi.org/10.1385/ABAB:118:1-3:205. 
56. Vats, P.; Banerjee, U.C. Biochemical characterisation of extracellular phytase (myo-inositol hexakisphosphate phosphohydrolase) from a hyper-producing strain of Aspergillus niger van Teighem. Journal of Industrial Microbiology and Biotechnology 2005, 32, 141-147, https://doi.org/10.1007/s10295005-0214-5.

57. Zhou, X.-L.; Shen, W.; Zhuge, J.; Wang, Z.-X. Biochemical properties of a thermostable phytase from Neurospora crassa. FEMS Microbiol Lett 2006, 258, 61-66, https://doi.org/10.1111/j.15746968.2006.00205.x.

58. Wyss, M.; Brugger, R.; Kronenberger, A.; Rémy, R.; Fimbel, R.; Oesterhelt, G.; Lehmann, M.; van Loon, A.P. Biochemical characterization of fungal phytases (myo-inositol hexakisphosphate phosphohydrolases): catalytic properties. Appl Environ Microbiol 1999, 65, 367-373, https://doi.org/10.1128/AEM.65.2.367373.1999.

59. Aghaie-Khouzani, M.; Forootanfar, H.; Moshfegh, M.; Khoshayand, M.; Faramarzi, M. Decolorization of some synthetic dyes using optimized culture broth of laccase producing ascomycete Paraconiothyrium variabile. Biochemical Engineering Journal 2012, 60, 9-15, https://doi.org/10.1016/j.bej.2011.09.002.

60. Salem, S.S.; Mohamed, A.; El-Gamal, M.; Talat, M.; Fouda, A. Biological decolorization and degradation of azo dyes from textile wastewater effluent by Aspergillus niger. Egyptian Journal of Chemistry 2019, 62, 1799-1813, https://doi.org/10.21608/EJCHEM.2019.11720.1747. 